\title{
Implementation of Operational Assistance Policy in Madrasah (Case Study of the Implementation School Operational Assistance Policy Management in Improving Madrasah Quality in East Java)
}

\author{
Pardi Arif Darmawan Bambang Kusbandrijo
}

\begin{abstract}
This study aims to describe and analyze the implementation of the School Operational Assistance policy, find out the supporting and inhibiting factors for implementing School Operational Assistance policies in madrasas, and find a model of implementing management policies in improving the quality of madrasas in the Regional Office of the Ministry of Religion of East Java.This type of research is descriptive qualitative. Researchers describe, analyze and interpret policies to improve the quality of madrasa education. The subjects of this study are; (1) Regional Office of Ministry of Religion of East Java, (2) Head of Madrasah Education Head of Regional Office of Ministry of Religion of East Java, (3) Head of Madrasah Education Section of Sidoarjo Regency, and (4) Head of Madrasah recipient of School Operational Assistance. Data collection using in-depth interviews and observation methods. The data analysis technique used in this study was inductive using phenomenological procedures. The results of this study indicate, the implementation of the School Operational Assistance policy in madrasas is carried out to improve access, quality, equity and quality of madrasa education. The existence of the program received support and positive responses from the madrasa management. Factors supporting the implementation of the policy are guidelines and technical guidelines, preparation of Madrasah Work Plans (RKM), assistance to madrassas, and higher public awareness. Community awareness factor in becoming the main supporting factor in implementation. The madrasah education quality development model is carried out with a variety of programs and activities whose budgets are taken from the School Operational Assistance funds. Many madrasa managers utilize School Operational Assistance funds to improve the quality and quality of education by strengthening the competence of teaching staff, improving facilities and infrastructure, strengthening graduation standards, and increasing the availability of reference access, whether in the form of books, magazines, scientific journals, and other sources learning can be used.
\end{abstract}

Keywords:Madrasa policy, implementation, quality

DOI: $10.7176 / \mathrm{JRDM} / 61-06$

Publication date: November $30^{\text {th }} 2019$

\section{INTRODUCTION}

1.1 Background of the Problem

The government is obliged to provide education services for citizens, especially basic education. The 1945 Constitution of the Republic of Indonesia Article 31 paragraph 1 states that every citizen has the right to education. The government strives and organizes national education that enhances faith and piety to God Almighty and noble character in educating the life of the nation which is regulated in the law (article 31 verse 2). For this reason, all components of the nation must develop the life of the nation which is one of the goals of the Indonesian state.

Whereas Law Number 20 Year 2003 concerning the National Education System mandates that every citizen aged 7-15 years must attend basic education. Article 34 paragraph 2 states that the government and regional governments guarantee the implementation of compulsory education at the minimum level of basic education without charging fees, in paragraph 3 it states that compulsory education is the responsibility of the state organized by government educational institutions, regional governments (Pemda), and the community.

As a consequence of the mandate of the law, the government and regional governments are required to provide education services for all students at the elementary level (elementary and MI, junior high and MTs) and other equal education units. The Ministry of Religion which handles madrasa education and pesantren has the responsibility to carry out the mandate of the Act to participate in achieving the completeness of educational services.

The National Education System Law No 20/2003 has positioned madrassas as a national education subsystem. Various breakthroughs and policies have been taken by the Ministry of Religion in order to play its strategic role in the field of education. For this reason, since 2014, there have been three policies regarding the important role of the national education subsystem, namely:

1. Equitable distribution and expansion of access to madrasa education;

2. Increasing the quality, relevance and competitiveness; and

3. Governance and accountability.

Factually, for equal distribution and expansion of access to education in madrassas has reached more than 
$90 \%$ if we look at data on the establishment of new madrasas that continue to grow and even seem overwhelmed because it was applied to the application of the establishment of operational licenses for new madrasas to be controlled systemically.

While efforts to accelerate the improvement of madrasa education quality, the relevance of budget use to program activities as well as madrasa competitiveness and governance, are still phenomena that need attention. This should be explored as a problem or imbalance between government policies and the reality in madrassah, As stated in the Strategic Plan for Islamic Education 2010-2014, namely how to improve the quality and governance of madrasa education in accordance with national education standards as regulated by Government Regulation No. 19/2005. Law No. 20/2003 implies equal opportunities for madrasas to obtain recognition, appreciation and not be discriminated against. Education in madrasas (there have been many examples both public and private) is increasingly proven by its hard work able to strengthen the competitiveness and quality of madrasa education in the national education arena. This is in line with the affirmation of article 17 paragraph (2) and article 18 paragraph (3) of Law No. 20 of 2003 concerning National Education System. Therefore madrasas need to work hard and make continuous improvements so as not to lag behind quality with public education (schools).. From empirical observations, the quality of madrasas in general still tends to focus on the knowledge and skills mastered by students. Indeed, it is very often discussed philosophically and theoretically that students must have creativity, intention, taste or students have brains, hearts and minds, but in the end the quality still returns to how far students have mastered the knowledge and skills that have been taught in madrasas. Even more ironic, students' knowledge is estimated by a superficial approach, namely the ability to memorize.

School Operational Assistance (BOS) is a government program that is basically to provide funding for nonpersonnel operational costs for basic education units as implementers of compulsory education programs. According to Government Regulation 48/2008 concerning Education Funding, non-personnel costs are costs for consumable educational materials or equipment, and indirect costs in the form of power, water, services, telecommunications, maintenance of facilities and infrastructure, overtime pay, transportation, consumption, taxes, insurance, and others. However, there are several types of personnel financing that are allowed to be financed with BOS funds. During its development, the BOS program experienced an increase in unit costs and the mechanism for distribution requirements. The mechanism for channeling BOS funds to public madrasas and private madrasas has changed, namely in 2016 for 500 MIN channeling of BOS funds through the DIPA Office of the Ministry of Religion and for MTsN and MAN still through each DIPA madrasa with the spread in activities accounts that are in accordance with madrasa planning. Whereas for private madrassas go directly to madrasah accounts or through other policies established by the Ministry of Religion for timely and targeted implementation through work contracts with PPK (Commitment Making Officials) and recipient receipts signed by the Madrasah Head. From the explanation above, it is necessary to study further about how the implementation of madrasa quality development that has been categorized as superior and not superior in East Java. So that madrasas can develop competitively in the current era of global competition, it is necessary to manage quality improvement in order to be able to compete on national and international maps. Therefore madrasas really need skills to improve their quality in the effort to guarantee quality of madrasas.

This study is entitled "Implementation of Operational Assistance Policy in madrasas: a case study on the implementation of BOS Management in improving madrasa quality in East Java". This research has an important contribution in making policy of school operational assistance to madrasas to spur improvement in madrasa quality in all aspects. This research has a general focus on madrassas in East Java and specifically in Sidoarjo Regency which receives BOS but still receives funding assistance from other parties. In addition, there are madrasas that only accept BOS as the main source of education funding within the East Java Province regional office. Thus this research is more focused on data collection and related to the impact caused by the BOS policy on madarasah more specifically in terms of improving madrasa quality since the implementation of BOS in madrassas which began to be handled by the Regional Office of the Ministry of Religion of East Java Province in 2013

\subsection{Research Problem Formulation}

Based on the background description of the problem, the following research problems are formulated:

1. How is the implementation of BOS management in improving madrasa quality at the Regional Office of the Ministry of Religion of East Java?

2. What are the supporting and inhibiting factors for the implementation of the School Operational Assistance policy in madrasas at the Regional Office of the Ministry of Religion of East Java?

3. What is the madrasah quality development model for recipients of School Operational Assistance in madrasas in East Java?

\subsection{Research Objectives}

1. Describe and analyze the implementation of the School Operational Assistance policy in madrasas at 
the Regional Office of the Ministry of Religion of East Java.

2. Knowing the supporting and inhibiting factors in implementing School Operational Assistance policies in madrasas at the Regional Office of the Ministry of Religion of East Java

3. Finding the model of BOS management policy implementation in improving madrasa quality at the Regional Office of the Ministry of Religion of East Java.

\section{LITERATURE REVIEW}

\subsection{Prior Research}

After conducting a literature review of the results of previous research, there are several studies related to the research title "Implementation of Operational Assistance Policy in Madrasas: Case Study of Boss Management Implementation in Improving the Quality of Madrasas in East Java" to be carried out. The author found several previous studies that are relevant to the issues discussed in this study. Among the results of previous studies conducted by Kiky, Gede Indra Surya Diputra (2005), Yanuarto (2016), Subangun (2017), Gutri, Hidayat, Hayu (2014), Kaswandi (2014), Afrilliana Fitri (2014), Gede Indra Surya Diputra (2016), Satrio Indra Febriantoro, Hery Sawiji, and Patni Ninghardjanti (2015), Saka Perdana (2013), Erianti1, Murniati, AR2, Niswanto2 (2017), Dinda Sukmawati (2016), Julianti Pontoh 1, Ventje Ilat 2, Hendrik Manossoh 3 (2015), Muhammad Wirawan, Bambang Satoso Haryono, Minto Hadi (2016), Asep Ediana Latip, Nafia Wafiqni (2017), Helis Setiani (2006), Roestoto Hartojo Putro, SU (2014), Warsiyanto (2011), Hani Latifah (2017), Muhammad Ramadhansyah (2014), Suheimy, Darwanis, Syukriy Abdullah (2016), Wa Reni (2016), Seye Abimbolaa, Rose Amazanb, Pavle Vizintina, Leanne Howiec, Robert Cumminga and Joel Negina (2016), Husain Salilul Akareemaand Syed Shahadat Hossainb (2016), Arasa and Zulkarnain Mohammeda (2018), Robin Clark and Jane Andrews (2014), Dilly Fung (2017), George R. Lueddeke (2014), Colin McCaig (2016), Fay Patel (2015), Malcolm Tight (2017), Maman Rusmana and Agus Hamdani (2015), and Fahrurrozi (2012).

\subsection{Comparison of Prior Research with Current Research}

From previous studies it was found that operational assistance policies on madrasas through BOS to improve madrasa quality have been carried out by several researchers, including Kiky Bagus Waluyo, Gede Indra Surya Diputra, Yanuarto, Subangun, Kaswandi, Afrilliana Fitri, Saka Perdana, Dinda Sukmawati, Maman Rusmana, Agus Hamdani, and Fahrurrozi. The previous research had similarities in the object of study with research conducted by Supardi, namely studying BOS management (in terms of Kiky Bagus Waluyo and Yunarto), the influence of BOS funds (in terms of Gede Indra Surya Diputra), management of BOS funds (according to Kaswandi and Afrilliana terms Fitri), BOS funding policies (in Saka Perdana's term), educational operational assistance programs (in terms of Dinda Sukmawati), operational policies in madrasas (in Supardi's terms), determination of BOS budgets (in terms of Maman Rusmana \& Agus Hamdani), and financial management madrasa (in Fahrurrozi's terms)

The main difference of the ten previous studies with the current research is related to the perspective or perspective of the study conducted. Kiky Bagus Waluyo and Fahurrozi were more focused on how to manage BOS to improve the quality of education in general, Yanuarto was more focused on how the influence of BOS funds in general. Gede Indra Surya Diputra is more focused on the influence of BOS on student achievement, Afrilliana Fitri is more focused on the concept of managing BOS funds, Kaswandi and Dinda Sukmawati is more focused on evaluating the management of BOS funds, Saka Perdana is more focused on the implementation of BOS funds, Maman Rusmana \& Agus Hamdani is more focused on the BOS funds budget policy. Whereas the current research focuses more on the implementation of BOS fund management to support quality improvement in madrasas.

\subsection{Theoretical basis}

\subsubsection{Public Policy}

Policy or policy is a set of concepts and principles that form the basis of a plan in the implementation of a job, leadership and way of acting (about government and organizations). According to Anderson (1979: 50) State policy basically reflects a relationship between government units and their environment. State policy is what the government chooses to do or not do. Anderson also stated that state policies as a series of actions that have certain goals are recognized and implemented by actors or groups of actors, in order to solve certain problems.

As according to Thomas R. Dye (1978), state policy is "whatever is chosen by the government to do or not do." While Easton (1988), gives meaning to state policy as "the allocation of values by force (syah) to all members Public. Easton also believes that the input, of a policy, is demand and support, that is, community demand and support for available resources.Anderson (1979) defines wisdom in a very broad sense as "the relationship of government unit to its environment". Anderson then points out the components that are in public policy: 1). Public Policy is the policy developed by officials or government bodies; 2). Policy demands are demands directed at public officials by other actors to do something based on problems; 3). Policy decisions are 
decisions made by public officials who have the authority to regulate and provide content on public policy actions; 4). Statement of Policy is a statement or articulation of public policy officially; 5). The Result of Wisdom is the manifestation of public policy that is clearly visible; 6). Impact of Wisdom is a consequence that arises in the community, whether intentional or not, caused by actions taken by the government. Anderson tried to separate the stages of wisdom into 6 stages: (1). Problem formulation: What are the public problems? What makes it a public problem? How can that problem be on the government's agenda?.(2). Selection: How can alternatives related to the problem be developed? Who is involved in the formulation of wisdom?. (3). Adaptation: How are alternative policies adopted? What conditions must be met? Who adopted wisdom? What process will be used? What is the content of the adopted wisdom.(4). Implementation: Who is involved? What is done, so that wisdom has an effect? What impact does the policy content have?. (5). Evaluation: How are the effectiveness and impact of wisdom measured? Who evaluates wisdom? Are there new demands that will change policy? (Samodra Wibawa, 1992, pp. 10-12)).

Based on the description above it can be concluded that state policy is a series of actions determined and implemented by the government which has a goal or is oriented towards a particular goal in the public interest. Or in other words, philosophically it can be said that state policy is the answer to the problems and needs of the community, so it is hoped that state policy is always in accordance with the interests of the community.

The stages of public policy according to William Dunn are as follows: (1) Formulation of the Agenda, (2) Policy Formulation, (3) Adoption of Policy Legitimacy, and (4) Policy Assessment / Evaluation. It is important to know why we must know and understand every policy, because policies cannot be understood textually, but there are many things that are contextual that are not known by the public in setting policies. This is where the role of the media as a facilitator for information transformation to the people. Then every minute must be independent or not influenced by certain political powers. In addition to the media as a tool, the community's role is to be able to analyze each policy and be able to help develop existing policies. These are the two objectives of studying government policy.

\subsection{Policy Implementation.}

Policy implementation is an important aspect of the entire policy process. Udoji even said that the exercise of wisdom is important in making wisdom. Wisdom will only be in the form of dreams or good plans that are stored neatly in the archive unless implemented (Udoji, in Abdul Wahab, 1990, p.45).

Grindle explains as follows: (1) The policy implementation process can begin if the goals and objectives that were originally general are detailed, action programs have been designed and a number of funds are allocated to realize those goals and objectives (Grindle , 1980, p.7). To achieve the final goal (2) There needs to be an implementation system that includes two aspects that must be considered in policy implementation activities, namely the content of the policy and the context of policy.

The contents of the policy include elements: 1) the interests that are affected, 2) the types of benefits, 3) the degree of expected change, 4) the position of the decision maker, 5) the implementation of the program, 6) the resources involved. Implementation of wisdom will be seen from the quantity of interests involved. The more interests that are affected, the more likely there is a conflict of interest, which will hamper program implementation.

Wisdom that clearly provides realizing benefits will be easier to implement. Programs that provide collective benefits that can generate joint demands will be more easily implemented because there will not be many conflicts because the benefits derived from the particularistic program will create competition for program benefits, making it difficult to implement.

According to Van Meter and Van Horn (Subarsono, 2005: 99) there are five variables that influence policy implementation, namely: "(1) standard and policy objectives; (2) resources; (3) communication between organizations and strengthening activities; (4) characteristics of the implementing agent; and (5) social, economic and political conditions (6) Disposition of implementers ... ".

Policy implementation is basically an interaction process of setting goals and actions in the form of programs and activities that have been set. The interaction will be influenced by internal and external factors. Internal conditions, related to the executor of the policy, its organization (character, culture, performance, coordination), costs and other supporting elements needed in implementing the policy. While external factors, including the support of the political system, such as parliamentary institutions for political support, social environment and public opinion on policy.

Jones's opinion asserted that the organizing activities related to efforts to set and reorganize resources, units, and methods that lead to efforts to realize (realize the policy) to be an outcome in accordance with the goals and objectives of the policy. Efforts to interpret (interpret) the substance of a policy in a language that is more operational and easier to understand, so that the substance of the policy can be implemented and accepted by the actors and policy targets. Then the application activities with respect to efforts to provide routine services, payments or other in accordance with the objectives and existing policy facilities. In the context of this study, 
using the Jones theory would like to know the implementation of BOS policies in the Ministry of Religion of East Java Province.

\subsection{Education Quality Policy}

\subsubsection{Madrasa Education Quality}

This quality improvement policy is one of the national policies and regional policies in improving the implementation of education as an effort to improve management, namely management of quality improvement based on the central government, becoming a management policy for quality improvement based on schools and communities. Social capital in this concept becomes very important to be strengthened, as the current policy to improve the quality of education involves the community.

Historically, the policy to improve the quality of education involving the community was based on the failure to centralize education delivery which only gave rise to formalism in education, lacked respect for plurality, and the truth was only in the central government, top down and had led to the arrogance of public schools towards private schools, while the quality of the process and educational outcomes are not jacked up and not lifted (Arif, 2009).

The aspects that can be worked on by the school within the framework of decentralized education include: (1) planning and evaluating school programs, (2) managing curriculum, (3) managing teaching and learning processes, (4) managing management, (5) managing equipment and equipment, (6) finance, (7) student services, (8) community school relationships, and (9) school climate management.

\subsubsection{Madrasa Quality Culture Strategy}

Continuous quality improvement is a hallmark of quality control management. Therefore, to develop a culture of quality madrasa madrasa head is demanded to continue to improve the quality of education in a sustainable or continuous manner. If the continuous improvement in the quality of education refers to the Deming Cycle At the same time there was a transition period (transition) to the attitudes, behaviors, values and culture of the old organization to adapt to the new environment that is a work environment based on a strong quality culture. Every change, like it or not, should touch values. Change without touching and transforming values, humans will continue to do the same things or ways as they did before. Quality culture is an organizational value system that produces an environment conducive to the continuity and sustainability of quality improvement. Quality culture consists of values, traditions, procedures, and expectations of quality promotion (Nursyabani Purnama, 2006).

\subsection{Critical Review}

From various studies conducted by Afrilliana Fitri (2014), Saka Perdana (2013), Kiky Bagus Waluyo, Roestoto Hartojo Putro, (2014), Asep Ediana Latip, Nafia Wafiqni (2017), Muhammad Ramadhansyah (2014), Subangun (2017) , Kaswandi (2014), Satrio Indra Febriantoro, Hery Sawiji, and Patni Ninghardjanti (2015), Erianti, Murniati, AR, Niswanto (2017), Julianti Pontoh, Ventje Ilat, Hendrik Manossoh (2015), Hani Latifah (2017), Seye Abimbolaa, Rose Amazanb, Pavle Vizintina, Leanne Howiec, Robert Cumminga and Joel Negina (2016), Husain Salilul Akareemaand Syed Shahadat Hossainb (2016), Arasa, and Zulkarnain Mohammeda (2018), Robin Clark and Jane Andrews (2014), Dilly Fung (2017), Colin McCaig (2016), Fay Patel (2015), Helis Setiani (2006), and Warsiyanto (2011).

Based on the research results above, the researcher will deepen the study by looking at the success and failure levels of the implementation of BOS and what are the supporting and inhibiting factors so that the BOS program is said to be successful or failed. In the context of this research, the BOS program as part of the government program in education will be analyzed with the knife of public policy. Furthermore, researchers with a knife of analysis from Mazmanian and Sabatier will build a model of BOS policy implementation so that in the future it will be better and quality.

\section{RESEARCH PROCEDURES}

3.1. Foundation of Qualitative Research Philosophy

Ontology of science includes science itself. What is the nature of truth and reality inherent in scientific knowledge that cannot be separated from the philosophical perception of what and how (which) "exists" (being, Sein, het, zijn). Epistemology of science, including sources, facilities and procedures for using these facilities to achieve (scientific) knowledge. Axiology includes values that are normative in giving meaning to truth or reality as we encounter them in our lives exploring various regions, such as social, symbolic or physical material areas. This research is categorized as descriptive qualitative. This study seeks to describe, analyze and interpret BOS policies in improving the quality of madrasa education. The qualitative approach was chosen by the researcher because, first because of the research questions raised. In qualitative research, research questions often begin with the words how and / what. These words lead to a flow of thinking "What happened" and "How did it happen". 


\subsection{Research Objects and Informants}

The object of research is the focus of this study in general on madrassas in East Java and specifically on madrassas in Sidoarjo Regency who receive BOS from the Madrasah Ibtidaiyah to Madrasah aliyah levels. Because in Sidoarjo there are also madrassas that only accept BOS as the main source of funding. On the other hand there is one madrasa, Madrasah Ibtidaiyah Darul Falah Sidoarjo, which does not want to receive BOS in the East Java Provincial Regional Office. With the case study model it is intended to focus more on data collection and the related impacts of the BOS policy on madrasas, more specifically on the side of improving madrasa quality.

The subjects in this study were those who were actively or inactive in the madrasah BOS policy in East Java. They will be key informants (key information) in this Research. They are; (1) Regional Office of Ministry of Religion of East Java, (2) Head of Madrasah Education Head of Regional Office of Ministry of Religion of East Java, (3) Head of Madrasah Education Section of Sidoarjo Regency, and (4) Head of Madrasah

\subsection{Method of collecting data}

In order to obtain accurate and credible data, this research will use several data collection techniques. Data collection techniques are very diverse. In this study will use in-depth interviews and observation methods as follows:

1. In-depth interview. According to Hadi (2004) interview is a method of data collection by a unilateral question and answer method which is done systematically and based on research objectives. In this study the interview is the main tool in exploring how and what is the implementation of madrasa BOS policies in East Java

2. Observation. According to Hadi (2004) stated that observation is a systematic observation and recording of the phenomena under study. Observations in this study are used to observe the social environment of research subjects.

In the context of validity (data accuracy), the validity of qualitative data according to Creswell (2010) is an examination of the accuracy of research results by applying certain procedures, while qualitative reliability indicates that the approach used by researchers is consistent if applied by other researchers.

Data validation by triangulation in research through significant others such as the subject, husband of the subject, nephew of the subject, subject children who are nonretarded. The results of interviews with the subject are checked with different sources which in this case are significant others as mentioned above. Checking focused on themes that researchers have found based on interviews.

\subsection{Data Analysis Techniques}

Data analysis is the final process in qualitative research (Creswell, 2010). Data analysis techniques or methods used in this study are inductive using phenomenological procedures (Moleong, 2007). The technique was chosen because this research will begin with typical findings in the field which are then interpreted in general.

\section{IMPLEMENTATION OF BOS MANAGEMENT TO IMPROVE MADRASAH QUALITY}

\subsection{Implementation of BOS Management Policy}

The government policy on School Operational Assistance has been running in the madrasa environment since 2009. Almost all madrassas within the Regional Office of the Ministry of Religion of East Java have received BOS starting from the Madrasah Ibtidaiyah (MI), Madrasah Tsanawiyah (MTs), and Madrasah Aliyah (MA) levels. This is as the result of interviews from the heads of MI, MTs, and MA who were informants in this study. However, there were some madrassas who did not receive BOS funds because of the foundation's policy. Chief of the Supreme Court in Sidoarjo said that his madrasa had received BOS funds since it was first programmed by the government. According to him, in the past the madrasa received Rp. 500,000 to Rp. 1,000,000, now expanding to Rp. 1,400,000 (Interview, Head of Supreme Court May 22, 2019).

Madrasah head's statement related to the technical guidelines above shows that the awareness of every BOS recipient madrasa has been embedded to follow the provisions of BOS fund management through the stipulated technical guidelines. This awareness will have a positive impact on government steps in improving the quality of education. Madrasas that receive BOS, can use it to meet the needs to improve the quality of education in madrasas and achieve National Education Standards (SNP). In the SNP, there are 8 component standards that must be met, namely:

1. Graduates' Competency Standards

2. Content Standards

3. Process Standards

4. Educator and Education Staff Standards

5. Facilities and Infrastructure Standards

6. Management Standards

7. Financing Standards 


\section{Assessment Standards}

The technical guidelines do not limit the detailed use of BOS funds for the eight standard components. So madrasas in this case, can be different in planning the use of BOS funds, depending on which sector is preferred by madrasas. But in general, madrasas share the average of the eight existing BOS funds.

Every madrasa has a target to be achieved in order to strengthen its institution as a quality madrasa. BOS funds are expected to be able to encourage the achievement of these targets, with careful planning from the madrasa in the distribution and use of BOS funds.

\subsection{BOS in Equitable Access to Education}

The BOS Program was created by the government with various objectives to be achieved, including: (1) Assisting the operational costs of non-personnel schools; (2) Increase the Gross Enrollment Rate (GER); (3) Reducing dropout rates; (4) Realizing government alignments (affimative action) for poor students by waive (fee waive) and / or help (discount fee) bill for school fees and other costs at school; (5) Providing equal opportunity for poor students to obtain affordable and quality education services; (6) Improve the quality of the learning process in schools.

Of the various objectives of the BOS funds above, one that has seen success is reducing school dropout due to financial factors. This can be seen from the results of interviews that the authors have done. All informants from various madrasas interviewed by the author claimed that there had never been students from their madrasas who had dropped out of school due to economic factors.

The facts conveyed by the madrasa head above are good news for the implementation of BOS fund management. Although there are still many goals to be achieved, at least that is one sign that BOS funds have been able to fulfill their objectives. Furthermore, it all depends on the madrasa policy in developing the quality of education in its institutions by making the best use of BOS funds provided. In education, the government targets every educational institution to be able to achieve the Minimum Service Standards (MSS), and for institutions that have reached the MSS, it is expected to reach the National Education Standards (NES). To achieve this, madrasas must work hard to make use of available resources. Therefore, many madrassas are seeking financial income other than BOS funds. An example is the policy carried out by madrassas in the form of fees and contributions received from the community / parents / guardians of students following the principle of non-profit and managed with the principles of transparency and accountability.

In this case, the efforts of the madrassas to strengthen their financial foundations, especially in the madrassas in the Sidoarjo region, did not involve any detailed interference or supervision from the Ministry of Religion. This is based on information submitted by the Chief Justice of the Supreme Court stating that in the collection problem there is no special supervision conducted by the Regional Office of the Ministry of Religion. Because according to him it was a local policy of the madrasa, so the Regional Office did not supervise in detail (Interview of the Supreme Court Chief Justice May 22, 2019)

The implementation of BOS policy in madrasas received positive responses from madrasa managers. The chairperson of the foundation, the head of the madrasa, the teaching staff, the parents, and the leaders in the Ministry of Religion who are related to madrasa education. The synergy between the Ministry of Religion and madrasas in the planning of BOS funds, will have a positive impact in leading the achievement of BOS objectives. Equitable access to education will be achieved, because every madrasa has used BOS according to the procedures and needs of the madrasa itself. So that the success of the BOS program is the responsibility of all parties involved in seeking to develop quality and expand access to education.

\section{SUPPORTING FACTORS AND INHIBITION OF BOS IMPLEMENTATION IN MADRASAH}

\subsection{Supporting Factors for BOS Implementation}

The implementation of BOS funds has a variety of supporting factors that make it easy for both madrassas in their management, as well as for the community to feel their usefulness. These supporting factors include:

1. Technical Guidelines

Technical Guidelines (Technical Guidelines) for BOS funds are guidelines for policy direction in the context of conducting processing and utilization that lead to improvements and improvements to the mechanism and structural system in substance and accidents.

The government provides the BOS funding program with technical guidelines (technical guidelines) so that madrasah recipients of BOS can use the assistance in accordance with established standards. The aim is nothing else so that the BOS program is able to achieve its main goal, improving the quality of Indonesian education.

These technical guidelines are mandatory provisions that must be obeyed by every BOS recipient. The existence of this technical guide actually facilitates the distribution of BOS funds in the education process, to ensure even distribution of quality in each sector needed. Madrasas as BOS recipients only need to adjust each plan in line with the general corridors set by the technical guidelines. 


\section{Has compiled RKM and RKT}

RKM is a comprehensive plan to optimize the use of all available and possible resources to achieve the desired goals in the future. RKM must be forward-looking and clearly how to bridge between current conditions and expectations to be achieved in the future. RKM must also pay attention to opportunities and threats from the external environment, paying attention to internal strengths and weaknesses. And then look for and find strategies and programs to take advantage of opportunities and strengths owned, overcome challenges and weaknesses that exist, in order to achieve the desired vision.

The objectives of preparing the RKM are as follows:

1. Ensuring that the objectives of the madrasah that have been formulated can be achieved with a high degree of certainty and a small risk.

2. Supporting coordination between madrasa stakeholders.

3. Ensuring the creation of integration, synchronization, and good synergy between madrasah actors, between madrassas and education supervisors, and between time.

4. Ensure linkages and consistency and planning, budgeting, implementation and supervision.

5. Optimizing the participation of madrassas and the community.

6. Ensure the achievement of the use of resources efficiently, effectively, fairly and sustainably.

RKT (Annual Work Plan) is a work plan used as a reference in carrying out madrasa activities for 1 year. It is important to have a RKT to provide direction and guidance for madrasah actors in order to change or aim for a better madrasa (improvement, development) with little risk and to reduce future uncertainty.

The RKT is expected to be used as: (1) work guidelines for madrasa improvement and development, (2) facilities for monitoring and evaluating the implementation of madrasah development, and, (3) material for proposing funding for madrasah development.

In the implementation of BOS, RKM and RKT are forms of planning in channeling BOS funds. All madrasa needs and programs are planned in the RKM and RKT, so if the BOS recipient madrasa already has both instruments, then the BOS implementation will run properly as desired.

3. Assistance from the Ministry of Religion

The implementation of BOS funds will also run well with assistance from the Ministry of Religion as the person responsible for this assistance program in the scope of madrasas. Assistance is needed starting from planning to reporting, so that BOS recipient madrassas manage the funds according to government programs. Assistance from the Ministry of Religion is carried out together, ensuring the formation of synergies in the success of government programs. It is hoped that madrasas can improve their quality through the correct implementation of BOS funds.

4. High public awareness

The general public is now aware of BOS funds. With high public interest in welcoming the existence of BOS funds, it certainly becomes a supporting factor for the implementation of BOS properlyIn the end, the implementation of BOS funds requires synergy from all parties, including the community. Because after all, the BOS funds were intended for them, so the community gave appreciation through various things, which had a very positive influence on the implementation of BOS in madrasas.

The community, especially student guardians, is the party who must know about the existence of BOS funds. Not only that, guardians of students are also required to know about the financial condition of madrasas. Madrasas have various programs to guarantee the quality of education in their institutions, and some of these programs cannot be covered by BOS funds. From the results of interviews conducted by the author, all informants stated that the operational needs of madrasas as a whole have not been fulfilled with BOS funds.

The data above shows the strong support of education practitioners in madrasas for the implementation of BOS policies in madrasas. The informant also said there were pluses and minuses in the implementation of the aid policy. Various obstacles were also experienced, especially the delay in disbursement.

\subsection{Inhibiting Factors of BOS Implementation}

There are supporting factors, so there are also factors that hinder the implementation of BOS funds. Based on the results of interviews by the author, there are two major problems that hamper the implementation of BOS funds, namely:

1. Management that is not transparent and accountable

Two important principles in financial management are transparency and accountability. The compatibility between the principles of transparency and accountability in running BOS programs or policies must be based or valuable as a space for public participation in general to participate in guarding. Lack of transparency in the management of BOS funds will diminish public trust. The management of BOS funds that are not accountable will also create problems, especially with those who supervise. Even though all madrassas claim to have applied the principles of transparency and accountability, it still must be noted that these two principles must be maintained by all parties. Because without holding on to these two principles, the implementation of BOS funds 
will be severely disrupted, both from internal and external institutions.

2. Disbursement of BOS funds which are often late

The delay in disbursing BOS funds was a major obstacle felt by all madrassas. The interview results show that madrasas find it difficult when funds that should be used immediately instead experience delays. The delay in disbursing BOS funds will indirectly disrupt the learning process. Madrasas, which should be able to focus on managing education, will instead be diverted to overcome the consequences of delays in BOS funds. These barriers encourage madrasas to go the extra mile in managing their finances. The quality of education must be maintained, therefore these various inhibiting factors are expected to be resolved soon, so that madrasah recipients of BOS can more easily carry out BOS implementation in accordance with established standards.

\section{MADRASAH QUALITY DEVELOPMENT MODEL FOR BOS RECIPIENTS}

6.1 BOS in improving access to education in madrasas

The BOS funding program aims to increase access to education. This assistance is expected to be able to expand the reach of education throughout Indonesia. Public and private educational institutions are expected to be able to improve quality comprehensively, so that the quality of Indonesian education can be evenly distributed. The BOS program is spread throughout Indonesia, and its scope is getting wider. This helps developing madrasas to spread their wings to achieve madrasas that meet the Minimum Service Standards (SPM) or even National Education Standards (SNP).

Regarding the BOS program in equalizing access to education, the Head of MTsN NU Sidoarjo stated as follows: "We feel that BOS has been able to achieve its objectives of equalizing and expanding access to education. Although there are still some shortcomings, but the main value that the government wants to instill has been achieved. I am sure with this the quality of education can be better, especially those of us in madrasas. "(Interview, Head of MTs NU Sidoarjo, 22 May 2019)

BOS as a means of achieving equal access to education, occupies an important position in the education space in Indonesia. With all its shortcomings, the BOS program is still very effective in supporting this goal.. In addition to the Medium Term Plan, another important instrument in the successful implementation of BOS in equalizing access to education is the Madrasa Budget and Madrasah Budget (RKAM). RKAM is a madrasa work plan in the short term, which is for one year. This plan contains various needs and programs that are immediately needed and implemented by madrassas. With this synergy, the BOS program will be easier to equalize Indonesian education. Madrasa's efforts in achieving national standards can be helped by BOS in the financial sector.

2. BOS in improving the quality of madrasa education

In addition to equalizing education, the main objective of the BOS program is to improve the quality of education. This is the spirit of this program, so that the quality of Indonesian education can be improved. The result of improving the quality of education is the creation of graduates who are ready to face the demands of the present age. One indicator of the quality improvement in madrasas is the fulfillment of the one book one child program as stipulated in the Book Law No. 3 of 2017 Article 61 paragraph (1). So far based on the results of the author's interview, many madrassas have not been able to fulfill the program.

Success in quality improvement depends on various programs from the madrasa. A good development model is needed to accelerate the achievement of quality targeted by the government. Based on the results of the writer's interview, all informants claimed that their madrasa had made various quality development models. Productive madrasas must be able to collaborate with their students in order to achieve the expected quality. Because without involving students, madrasas will not be productive and are considered to have failed in their learning.

The entrepreneurship development model such as the statement above is a good step to support the BOS program which still has some shortcomings. Madrasa entrepreneurs will get additional income, while increasing the quality that has been desired, both in learning and facilities. This is a form of achievement that should be an inspiration for other madrassas.

Related to this, the Head of MTs NU Sidoarjo also stated that the achievements in his madrasa were the result of developing students. According to him, the achievements achieved through students are clear evidence that madrassas have quality in their learning (Interview, Head of MTs NU Sidoarjo, 22 May 2019).

This innovation drives the improvement of madrasa quality, especially in implementing the BOS program. Innovation varies from one madrasa to another, seeing what the potential is there. Various breakthroughs have to be done, showing the community that madrasas can compete with public schools, and even become the best. This is not impossible, changing the views of the community who still assess public schools better than madrasas is possible. The way is, of course, with a variety of positive and innovative programs, to provide a breakthrough in the world of education today.

Collaboration with various parties will be able to open up the educational horizons in the madrasa, providing new inspirations for the achievement of quality education. As long as the management of BOS funds 
is in accordance with existing regulations, any program run by madrasas will have a major influence on the implementation of BOS, especially in strengthening the quality of education. According to the Head of Madrasah Education Division on one occasion stated as follows: "the nine things became the general policy direction of the development of education in madrassas prepared by the madrasa education sector in the context of developing the quality of madrasah achievements and thank God that all can run even though it has not been evenly distributed but is getting better but is getting better "(W.3.Kabid. 12-12-2018)

Thus from the document review and interview results it can be concluded that BOS policy is a unity of madrasa funds whose management is based on technical guidelines, Chart of Account Standards and Input Cost Standards (SBM). The BOS implementation policy begins with planning, implementation of disbursement, reporting and evaluation at the madrasah level. Then the ministry of religion controls by monitoring and evaluating and supervising its use massively and gradually from the center to the regions by involving all elements of authority. While the reporting is done openly and can be accessed by all madrasa and community stakeholders in general.

Finally, with all the synergy and efforts, the implementation of BOS will succeed in achieving its goals through the care of all relevant parties, both from the Ministry of Religion, madrasas, to the community. All of them collaborate and support each other for the sake of good quality education, so that this country will get young cadres of quality, character and competitiveness.

\section{IMPORTANT FINDINGS, RESEARCH IMPLICATIONS, AND PROPOSITIONS}

7.1 Important Findings

7.1.1. Madrasah BOS Implementation Policy

Referring to Permendiknas No. 19 of 2007 concerning Education Management Standards by the Elementary and Secondary Education Unit, each education unit in developing the quality of education must have a policy line in the form of a program concept that is used as a reference for madrasas / schools both in terms of curriculum, staffing, infrastructure and students. and public relations.

Based on the results of the document review, the researcher found the formulation of policy lines at the Ministry of Religion of East Java Province. According to Article 464 of the Regulation of the Minister of Religion of the Republic of Indonesia Number 13 of 2012 concerning Organization and Work Procedures of the Vertical Institution of the Ministry of Religion it is stated, that the Madrasah Education Sector Madrasa Education Sector as referred to in Article 464 paragraph (1) letter b has the task of carrying out services, guidance, coaching, and management of information systems in the field of madrasa education.

The BOS implementation policy in madrasas is also relevant to this task. In accordance with Article 472 Madrasah Education Sector Regional Office of East Java Province focuses on improving the quality of Madrasah Education, including through the use of BOS funds in financing education at madrasas at all levels.

More technically, as reviewed documentation in the field of East Java Pendma has five sections that have different roles and tasks in policy implementation. However, simultaneously the task remains synergistic to implement BOS policies in madrasas.

The BOS policy in madrasas has run well and has received positive responses from madrasa managers. All madrasa heads stated that they still wanted the BOS program to continue. More than that, the informant stated that it was necessary to increase the budget if possible. However, if this is not possible, it is sufficient to improve the administrative policy system of the BOS through various assistance programs as well as the administrative planning and reporting reform.

7.1.2. Supporting and inhibiting factors of BOS

Supporting factors for the implementation of BOS in madrasas support the smooth implementation of BOS policies and programs in education funding. In detail quite a lot of supporters. However, what was clearly obtained from the informants the supporting factors included: (1) the existence of Technical Guidelines, (2) had prepared RKM and RKT, (3) assistance from the Ministry of Religion, (4) high public awareness

7.1.3. Madrasah Quality Development Model with BOS

Based on research data, it was found that each madrasa differed in using BOS funds to improve the quality of education in madrasas. The development model that was carried out was different, because it was adjusted to the direction and mission of each madrasa.

Some of the concepts of development and quality improvement programs developed by madrasas based on document review in Madrasah Education in East Java Province include (1) curriculum development which includes Graduation Standards (SKL), Content Standards (SI) and Process Standards. (2) Improvement of the Competence and skills of the teaching staff and educational staff in many aspects both in terms of cognition, learning management, class mastery and many more. (3) Institutional development and management system of madrasas based on Madrasah-Based Quality Improvement Management (MPMBM). (4) Development of madrasah education facilities ranging from madrasas ibtidiyah, Tsanawiyah mdrasahs to Madrasah Aliyah in the form of organizational governance, correspondence management to fulfillment of facilities and prejudices 
formulated from GIS data (Geographic Information System) and Sim sarpras (management information system) Facilities and infrastructure). (5) The formation of the basic values and norms of madrasa citizens is based on 5 basic principles of madrasa culture, namely: a. Religiosity, b. Nationalism, c. Integrity, d. Independence, e. Together (6) Development of a meaningful Learning Model that is fun to foster student enthusiasm and creativity because departing from this concept will spur academic and non-academic achievements of madrasa students. (7) Development of English and Arabic language mastery programs as a basis for mastering science and technology such as mathematics, natural sciences, social sciences in the national and international arena. (8) Preparing madrasa graduates with global quality, morality and national and international competitiveness. (9) Sharpening the target of madrasa quality development programs, each madrasa certainly has different characteristics and capabilities both financial and supportive, therefore in the field Madrasa education in synergy up to the district and city level at the beginning of the school year always checking and evaluating Madrasah Work Plans (RKM) and at the beginning of the fiscal year by looking carefully at the Madrasah Activity and Budget Plans (RKAM) before carrying out the realization of BOS disbursements in madrasah

7.2.1. Theoretical implications

The results of this study criticize the concept of Robert Eyeston (1971), which defines public policy as the relationship of a government unit with its environment. In this case, public policy is emphasized as allocating the values of power for the entire society whose existence is binding. In this sense only the government can take an action on society and the action is a form of something chosen by the government.

The findings of this study support the concept of Thomas R. Dye defining public policy as "Whatever governments choose to do or not to do.", Ie everything or anything the government chooses to do or not do. Dye also interpreted public policy as an effort to find out what exactly was done by the government, why they did it, and what caused them to do it. He also said that if the government chooses to take an action, then the action must have a purpose. The public policy must cover all government actions, not just the wishes or government officials. In addition, even something that is not implemented by the government is a public policy.

As in the BOS program, the government chose this educational assistance program with a strong objective, namely to improve the quality of education in Indonesia. Whatever type and level of education. On the other hand, the objectives of this government are in line with the objectives of community-based education which then fully supports the education assistance policy through the BOS madrasa.

On the other hand, Richard Rose (1969), states that public policy should be understood as a series of activities that are more or less related to their consequences for those concerned rather than as a separate decision. This concept gives an understanding that policy is a pattern of activities not just a decision to do something.

7.2.2. Practical Implications

Practically the results of this study have implications for the management of BOS funds in madrasas. The School Operational Assistance Policy (BOS) has been realized with the support of the education community. however, madrassas that have educational development programs still receive assistance and donations from education fees from the community.

Models of developing the quality of education through BOS funds are implemented differently by madrasas. There is a development model that is carried out by increasing the competence of teaching staff, improving infrastructure, increasing literacy access, and various forms of programs implemented. This shows that BOS has practical implications that can be implemented by madrasa managers. The research findings above are the result of a research analysis by taking into account the concepts and theories that are used as references in this study. More clearly the findings of this study can be seen in the following chart: 


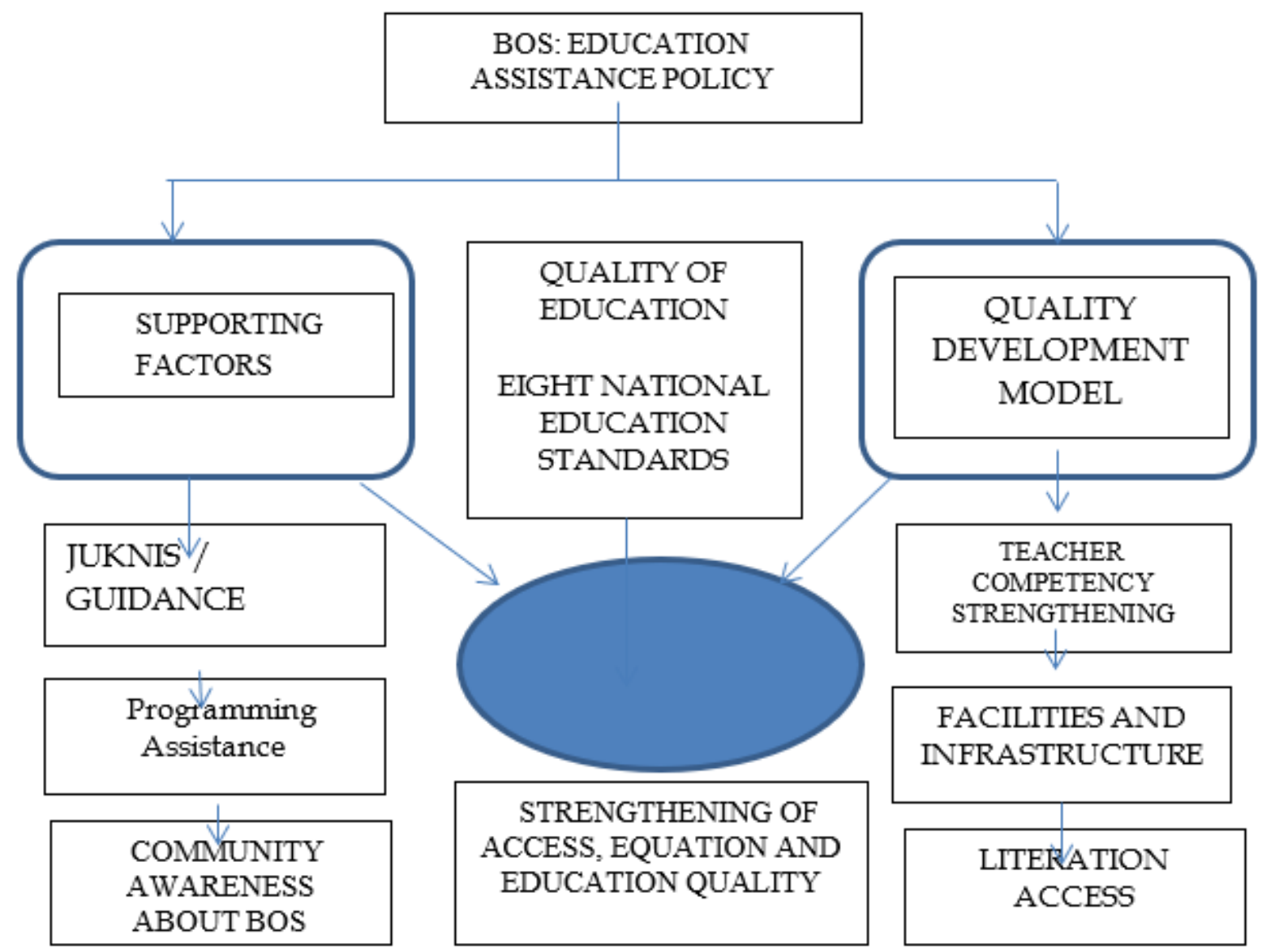

Source: Analysis results

\subsection{Proposition}

a. Government policies aimed at improving the quality of public education can increase public participation in education management. The community considers that the cost of education does not have to be borne by the government alone, but the community is also increasingly aware to help finance education.

b. Educational funding assistance can spur the management of educational institutions to conduct a model of quality development in schools in accordance with government objectives and community goals.

\section{CLOSING}

8.1. Conclusion

8.1.1 Implementation of School Operational Assistance policies in madrasas is carried out to improve access, quality, equity and quality of madrasa education. The existence of the BOS program has received support and positive responses from the madrasah management so that this BOS policy needs to be continued by improving the system, both planning, implementation, and reporting. Policy makers in this case the government are expected to increase the quantity of assistance with various programs aimed at. Meanwhile, madrasa managers in managing BOS funds refer to eight national education standards.

8.1.2 Supporting factors for the implementation of the School Operational Assistance (BOS) policy include the availability of guidelines and technical guidelines, preparation of the Madrasah Work Plan (RKM), assistance to madrasas, and increased public awareness. This public awareness factor in understanding BOS is the main supporting factor in the implementation of BOS policies in financing education in madrasas. The community increasingly understands that quality education requires funding for education that is greater than the amount of BOS funds received by madrasas. Thus community participation still appears tips in madrasas.

8.1.3 The model for developing the quality of madrasah education is carried out with a variety of programs and activities whose budget is taken from BOS funds. Many madrasa managers use BOS funds to improve the quality and quality of education by strengthening the competence of teaching staff, improving facilities and infrastructure, strengthening graduation standards, and increasing the availability of reference access, in the form of books, magazines, scientific journals, and other sources that can be used learning. 


\section{REFERENCES}

Agustino, Leo. (2008) Dasar-dasar Kebijakan Publik. Bandung: Alfabeta.

Amirullah dan Hanafi Rindyah, 2002, Pengantar Manajemen, Graha Ilmu, Yogyakarta.

Anderson, James E, 1979, Public Policy Making, Second Edition, New York.

Barnawi dan M. Arifin. 2012. Manajemen Sarana dan Prasarana Sekolah. Yogyakarta: Ar-ruzz Media.

Bellen, S., dkk., 2000, Manajemen Berbasis Sekolah, UNESCO-UNICEF-Pemerintah Indonesia, Jakarta.

Bush, Tony, 1986, Theories of Educational Management, Paul Chapman Publishing, London.

Bungin, Burhan, 2003, Analisis Data Penelitian Kualitatif, RajaGrafindo Persada, Jakarta.

Carlisle, Howard M., 1987, Management Essentials, Concepts for Productivity and Innovation, Science Reseacrh Associates, Chicago.

Cresswell, John W. Research Design. Quantitative \& Qualitative Approaches, 2002, New York: Sage Publication, Inc.

Denhardt \& Denhardt, 2003. The New Public Service. M.E Sharpe: New York Diknas. 2007. Buku Panduan Pelaksananan BOS Direktorat Jenderal Pendidikan Dasar dan Menengah. Jakarta: Diknas

Diknas. 2009. Rekapitulasi Penyaluran Dana BOS Tahun 2007-2008. Padang: Diknas.

Direktorat Jenderal Pendidikan Dasar Kementerian Pendidikan dan Kebudayaan Republik Indonesia. 2013. Petunjuk Teknis Penggunaan Dana Bantuan Operasional Sekolah (BOS) dan Pertanggungjawaban Keuangan Bantuan Operasional Sekolah Tahun Anggaran 2013. Jakarta: Kementerian Pendidikan dan Kebudayaan.

Dunn WN. Pengantar Analisis Kebijakan Publik. Yogyakarta : Gadjah Mada University Press:2003

Duhou, Ibtisam Abu, 1999, School-Based Management, UNESCO, Paris.

Dwiyanto, Agus. 2006. Reformasi Birokrasi Publik di Indonesia pusat Studi Kependudukan dan kebijakan. Universitas Gadjah Mada Yogjakarta.

Dye, Thomas R. 1995. Understanding Public Policy. New Jersey: Prentice Hall.

Easton, David. 1965. A System Analysis of Political Life. New York: Wiley.

Easton, Joseph W. (ed), 1986. Institutional Building and Development: From Concepts To Aplications, 1972 , (terjemahan), UI Press, Jakarta.

Edward III, George C, (1984) Public Policy Implementing, Jai Press Inc, London-England; (edited),

Edwards III. George C. (1983), Implementing Public Policy, Congressional Quarterly Inc. Wanshington Dc.

Etzioni, Amitai, 1996, The New Golden Rule, Basic Books, New York.

Evans G, Manning N, 2003. Helping Governments Keep Their Promises Making Ministers and Governments More Reliable Through Improved Policy Management Report No. IDP-187 South Asia Region- Internal Discussion Paper.

Gibson, Donnely, and Ivancevich, 1996, Manajemen (terjemahan), Air Langga.

Goggin, Malcolm L et al. 1990. Implementation, Theory and Practice: Toward a Third Generation, Scott, Foresmann and Company, USA.

Grindle, Merilee, S, 1980, Politics and Policy Implementation In The Third World, Princeton University Press, Princeton New Jersey.

Grindle, Merilee S and Thomes, John W., 1991. Public Choices and Policy Change : Political Economy of Review in Developing Courntries Baltimore and London. The John Hopkins University Press.

Guba, EG \& Lincoln, YS 1994, 'Competing paradigm in Qualitative research', in NK Denzin \& YS Lincoln (eds), Handbook of qualitative research, Sage Publications, Thousand Oaks, pp. 643-654.

Hatry, Harry P. et all., 1994, Implementing School-Based Management, Insight into Decentralization from Science and Mathematics Departement, The Urban Institute, Washington.

Hogwood Brian W \& Lewis A Gunn, 1984, Policy Analisis For The Real Word, Oxfort University Press, New York.

Hogwood, Brian W., and Gunn, Lewis A., 1986. Policy Analysis For the Real World, Oxford University Press.

Howlett, Michael and M. Ramesh, 1995. Stuying Public Policy: Policy Cycles and Policy Subsystem. Oxford University Press. Toronto-Newyork-Oxford

Islamy, Irfan M., 2002, Prinsip-Pronsip Perumusan Kebijaksanaan Negara, Bumi aksara, Jakarta.

Islamy, M. Irfan. (1991) Prinsip-prinsip Perumusan Kebijaksanaan Negara. Jakarta: Bumi Aksara.

Indrawijaya, Adam I., 1989, Perilaku Organisasi, Sinar Baru, Bandung.

Jones, Charles O., 1984, An Introduction to the Study of Public Policy, North Scituate Massachussets : Dux bury Press, California

Jones, Charles O., 1977, An Introduction to the Study of Publik Policy, Belmont CA: Wads worth.

Karding, Abdul Kadir.2008 "Evaluasi Pelaksanaan Program Bantuan Operasional Sekolah (BOS) Sekolah Menengah Pertama Negeri Di kota Semarang”(Tesis). Semarang: Universitas Diponegoro

Kementrian Pendidikan dan Kebudayaan. Direktorat Jendral Manajemen Pendidikan Dasar dan Menengah. 2007 Bantuan Operasional Sekolah (BOS) dalam Peraturan Perundang-Undangan. Jakarta 
Kementerian Pendidikan Nasional dan Kementerian Agama Republik Indonesia. 2013. Perencanaan dan Penganggaran Sekolah Pedoman Penyusunan Untuk Kepala Sekolah. Jakarta: Kementerian Pendidikan dan Kebudayaan.

Lasswell, H.D. dan Kaplan A., 1970, Power and Society, New Haven: Yale University Press.

Mazmanian, Daniel A and Paul A. Sabatier. 1983. Implementation and Public Policy, Scott Foresman and Company, USA

Miles, Matthew B. Dan A. Michael Huberman. 1992. Analisis Data Kualitatif : Buku Sumber tentang Metode Baru ( edisi terjemahan oleh Tjetjep Rohendi Rohidi). Universitas Indonesia. Jakarta

Moleong, J. Lexy. (2000) Metodologi Penelitian Kualitatif. Bandung: PT Remaja Rosdakarya.

Muhadjir, Noeng H., 1998, Metodologi Penelitian Kualitatif, Penerbit Rakesarasin, Jakarta.

Muslim, Faesol, dkk., 2000, Peran Serta Masyarakat dalam Pendidikan, UNESCO-UNICEF-Pemerintah Indonesia, Jakarta.

Neuman, WL 2003, Social Research Methods : Qualitative and Quantitative Approaches, 5th ed. edn, Allyn and Bacon, Boston ; London.

Nugroho, Riant. 2003. Kebijakan Publik Formulasi, Implementasi, Evaluasi. PT. Elex Media Komputindo : Jakarta.

Parson, W. (1997) Public Policy, An Introduction to the Theory and Practice of Policy Analysis. U.K, Aldershot Edward Elgar Publishing

Parsons Wayne, 2005. Public Policy : Pengatar Teori \& Praktik Analisis Kebijakan. 2001 Edward Elgar Publishing, Ltd, Edisi Pertama, Cetakan Ke-1

Peraturan Pemerintah Republik Indonesia nomor 47 tahun 2008 tentang Wajib Belajar.

Priatmoko, Dody Heriawan, 2003, Reformasi Pendidikan Indonesia, Suatu Solusi Keluar dari Krisis, Makalah dalam Website Balitbang Depdiknas. Jakarta.

Priyo dan Pantiwati. Analisis Pemantauan Outcome Program Bantuan Operasional Sekolah (BOS) Di Madrasah Tsanawiyah Gresik.

Program Bantuan Operasinal Sekolah (BOS) dalam Peraturan Perundang-undangan di Indonesia. Melalui: http//www.jdih.bpk.go.id

Putra Fadillah, 2003, Partai Politik dan Kebijakan Publik, Pustaka Pelajar, Yogyakarta.

Rahim, Husni, 2003, RUU Sisdiknas dan Reformasi Pendidikan Indonesia, (Makalah) UIN Syarif Hidayatullah, Jakarta.

Ridjal, Tadjoer, 2001, "Metode Bricolage Dalam Penelitian Sosial", dalam Bungin, Burhan, Metodologi Penelitian Kualitatif, RajaGrafindo Persada, Jakarta.

Ripley, Rendal B. and Grace A. Franklin. 1986. Policy Implementation and Bureaucracy, second edition, the Dorsey Press, Chicago-Illionis.

Rosyada, Dede, 2004, Paradigma Pendidikan Demokratis, Sebuah Model Pelibatan Masyarakat Dalam Penyelenggaraan Pendidikan, Kencana, Jakarta.

Robins and Coulter, 1996, Management, Prentice hall, Inc.

Rosfadhila, Neuthia dan Justin Sodo. Peran Komite Sekolah Dalam Pelaksanaan BOS: Sebuah Catatan Kritis. Jakarta: Lembaga Penelitian Smeru. Melalui: http//.www. smeru.or.id

Sabatier, P.A., and Mazmanian, D. 1979. "The Conditiong of effective Implementation" dalam policy Analysis. 5,481-504.

Sabatier, Paul. 1986. "Top down and Bottom up Approaches to Implementation Research" Journal of Public Policy 6, (Jan), h. 21-48.

Siagian SP. 1985. Analisis Serta Perumusan Kebijaksanaan Dan Strategi Organisasi. Jakarta : PT. Gunung Agung

Siagian, Sondang. P.2005. Administrasi Pembangunan, Konsep Dimensi dan Strateginya. Jakarta: Bumi Aksara.

Sinambela, Lijan. P, (2006). Reformasi Pelayanan Publik. PT. Bumi Aksara, Jakarta.

Soejono Soemargono. 1983. Filsafat Ilmu Pengetahuan. Nur Cahaya: Yogyakarta.

Subarsono AG. (2005) Analisis Kebijakan Publik Konsep Teori dan Aplikasi. Yogyakarta : Pustaka Pelajar

Subarsono, AG. (2011) Analisis Kebijakan Publik. Yogyakarta, Pustaka Pelajar.

Surya Utama. Dasar-Dasar Analisis Kebijakan Kesehatan (online) http: //repository.usu.ac.id/bitstream/123456789/3765/1/fkm-surya4.pdf. Jumat, 11 Maret 2011 pkl 15.31

Steers, Richard M,. 1985, Efektivitas Organisasi, Kaidah Perilaku, Erlangga, Jakarta.

Suharyo, Wijayanti et.al. 2006. Kajian Cepat PKPS-BBM Bidang Pendidikan Bantuan Operasional Sekolah (BOS) 2005. Jakarta: Lembaga Penelitian Smeru. Melalui: http//.www. smeru.or.id

Supriono, S dan Sapari Achmad, 2001, Manajemen Berbasis Sekolah, SIC, Surabaya.

Surat Edaran Menteri Pendidikan, nomor 186/MPN/KU/2008, tentang bantuan operasional sekolah, tahun anggaran 2009

Tilaar, H.A.R., 2000, Paradigma Pendidikan Nasional, Rineka Cipta, Jakarta. 
Tim Peneliti LP Smeru.2005. Pelaksanaan Program Bantuan Operasinal Sekolah (BOS) dan Akses terhadap Pendidikan Dasar bagi Masyarakat Miskin. Jakarta: Lembaga Penelitian Smeru. Melalui: http//.www. smeru.or.id

Tim Peneliti LP Smeru.Tanpa Tahun. Dampak Program BOS terhadap Penerimaan dan Pengeluaran Sekolah serta Tingkat Kepuasan Pemangku Kepentingan. Jakarta: Lembaga Penelitian Smeru. Melalui: http//.www. smeru.or.id

Undang-Undang Nomor 20 tahun 2003 tentang Sistem Pendidikan Nasional

Van meter dan Van Horn, 1978. Developing Performance Monitoring in public sector Organization, new York.

Wahab, Solichin Abdul, 2002, Analisis Kebijaksanaan, Dari Formulasi Ke Implementasi Kebijaksanaan Negara, Bumi Aksara, Jakarta.

Wahab, Solichin Abdul. (2001) Evaluasi Kebijakan Publik. Malang: Universitas Negeri Malang.

Walt G and Gilson L, 1994. Reforming the health sector in developing countries: the central role of policy analysis. Health Policy and Planning 9(4): 353

Wibawa, Samudra. (1994) Evaluasi Kebijakan Publik. Jakarta: PT. Raja Grafindo Persada.

Widodo. Joko. 2008. Analisis Kebijakan Publik (Konsep dan Aplikasi Proses Kebijakan Publik) Cetakan Kedua. Bayumedia Publishing : Malang.

Widoyoko, Eko, Putro. (2010) Evaluasi Program Pembelajaran. Yogyakarta: Pustaka Pelajar.

Winarno, Budi. 2007. Kebijakan Publlik Teori dan Proses, Edisi Revisi. Media Pressindo : Yogyakarta

Wooding S, Scoggins A, Lundin P, Ling T, 2004. Talking Policy An examination of public dialogue in science and technology policy. RAND Corporation Santa Monica, CA US.

Yin, RK. 1994. Case Study Research-Design and Methods, Applied Social Research Methods series Vol.5, $2^{\text {nd }}$ edn, Sage Publication, Newbury Park

Yuyun S. Suriasumantri. 1991. Ilmu dalam Perspektif. Gramedia: Jakarta.

Zamroni, 2000, Paradigma Pendidikan Masa depan, Bigraf Publishing, Yogyakarta.

UU RI No. 12 Tahun 2003, Sistem Pendidikan Nasional, Diterbitkan Oleh Lembaga Informasi Nasioanal, Jakarta. 2003. 